Biogeosciences, 10, 2671-2682, 2013

www.biogeosciences.net/10/2671/2013/

doi:10.5194/bg-10-2671-2013

(c) Author(s) 2013. CC Attribution 3.0 License.

\title{
Nitrous oxide emissions from European agriculture - an analysis of variability and drivers of emissions from field experiments
}

R. M. Rees ${ }^{1}$, J. Augustin ${ }^{2}$, G. Alberti ${ }^{3}$, B. C. Ball ${ }^{1}$, P. Boeckx ${ }^{4}$, A. Cantarel $^{5}$, S. Castaldi $^{6}$, N. Chirinda ${ }^{7}$, B. Chojnicki ${ }^{8}$, M. Giebels ${ }^{1}$, H. Gordon ${ }^{1}$, B. Grosz ${ }^{9}$, L. Horvath ${ }^{10}$, R. Juszczak ${ }^{8}$, Å. Kasimir Klemedtsson ${ }^{11}$, L. Klemedtsson ${ }^{12}$, S. Medinets ${ }^{13}$, A. Machon ${ }^{9}$, F. Mapanda ${ }^{14}$, J. Nyamangara ${ }^{15}$, J. E. Olesen ${ }^{7}$, D. S. Reay ${ }^{16}$, L. Sanchez ${ }^{17}$, A. Sanz Cobena ${ }^{17}$, K. A. Smith ${ }^{16}$, A. Sowerby ${ }^{18}$, M. Sommer $^{2}$, J. F. Soussana ${ }^{5}$, M. Stenberg ${ }^{19}$, C. F. E. Topp ${ }^{1}$, O. van Cleemput ${ }^{4}$, A. Vallejo ${ }^{17}$, C. A. Watson ${ }^{1}$, and M. Wuta ${ }^{14}$

${ }^{1}$ Scotland's Rural College (SRUC) Edinburgh, West Mains Road, Edinburgh EH93JG, UK

${ }^{2}$ ZALF, Eberswalder Straße 84, 15374 Müncheberg, Germany

${ }^{3}$ Department of Agricultural and Environmental Sciences, University of Udine, 33100 Udine, Italy

${ }^{4}$ Isotope Bioscience Laboratory, Ghent University, Coupure Links 653, 9000 Ghent, Belgium

${ }^{5}$ INRA, Grassland Ecosystem Research, UREP, Avenue du Brezet, 63039 Clermont-Ferrand, France

${ }^{6}$ Department of Environmental Science, University of Naples, via Vivaldi 43,81100 Caserta, Italy

${ }^{7}$ Department of Agroecology, Aarhus University, Blichers Allé 20, Postboks 50, D8830 Tjele, Denmark

${ }^{8}$ Meteorology Department, Poznan University of Life Sciences, Piatkowska 94, 60-649 Poznan, Poland

${ }^{9}$ Department of Meteorology, Eötvös Loránd University, Pázmány Péter sétány 1/a 1117 Budapest, Hungary

${ }^{10}$ Plant Ecology Research Group of Hungarian Academy of Sciences, Institute of Botany and Ecophysiology, Szent István University, Páter K. utca 1, 2100 Gödöllő, Hungary and Hungarian Meteorological Service, Gilice tér 39, 1181 Budapest, Hungary

${ }^{11}$ University of Gothenburg, Department of Earth Sciences, 40530 Gothenburg, Sweden

${ }^{12}$ University of Gothenburg, Department of Plant \& Environmental Science, S40530 Gothenburg, Sweden

${ }^{13}$ Odessa National II Mechnikov University, 65082 Odessa, Ukraine

${ }^{14}$ University of Zimbabwe, Harare, Zimbabwe

${ }^{15}$ International Crops Research Institute for the Semi-Arid Tropics (ICRISAT), Matopos Research Station, P.O. Box 776, Bulawayo, Zimbabwe

${ }^{16}$ University of Edinburgh, School of Geosciences, Edinburgh EH8 9YL, UK

${ }^{17}$ Polytechnic University of Madrid, Dpto. Química y Análisis Agrícola, ETSI, Agrónomos, C/Ciudad Universitaria s/n, 28040 Madrid, Spain

${ }^{18}$ Centre for Ecology and Hydrology, Bangor LL57 2UW, Gwynedd, UK

${ }^{19}$ Swedish University of Agricultural Sciences, Department of Soil and Environment, P.O. Box 234, SE-532 23 Skara, Sweden

Correspondence to: R. M. Rees (bob.rees@sruc.ac.uk)

Received: 13 June 2012 - Published in Biogeosciences Discuss.: 27 July 2012

Revised: 20 March 2013 - Accepted: 21 March 2013 - Published: 22 April 2013

\begin{abstract}
Nitrous oxide emissions from a network of agricultural experiments in Europe were used to explore the relative importance of site and management controls of emissions. At each site, a selection of management interventions were compared within replicated experimental designs in plot-based experiments. Arable experiments were conducted at Beano in Italy, El Encin in Spain, Foulum in Denmark,
\end{abstract}

Logården in Sweden, Maulde in Belgium, Paulinenaue in Germany, and Tulloch in the UK. Grassland experiments were conducted at Crichton, Nafferton and Peaknaze in the UK, Gödöllö in Hungary, Rzecin in Poland, Zarnekow in Germany and Theix in France. Nitrous oxide emissions were measured at each site over a period of at least two years using static chambers. Emissions varied widely between sites 
and as a result of manipulation treatments. Average site emissions (throughout the study period) varied between 0.04 and $21.21 \mathrm{~kg} \mathrm{~N}_{2} \mathrm{O}-\mathrm{N} \mathrm{ha}^{-1} \mathrm{yr}^{-1}$, with the largest fluxes and variability associated with the grassland sites. Total nitrogen addition was found to be the single most important determinant of emissions, accounting for $15 \%$ of the variance (using linear regression) in the data from the arable sites $(p<0.0001)$, and $77 \%$ in the grassland sites. The annual emissions from arable sites were significantly greater than those that would be predicted by IPCC default emission factors. Variability of $\mathrm{N}_{2} \mathrm{O}$ emissions within sites that occurred as a result of manipulation treatments was greater than that resulting from site-to-site and year-to-year variation, highlighting the importance of management interventions in contributing to greenhouse gas mitigation.

\section{Introduction}

Terrestrial sources of nitrous oxide $\left(\mathrm{N}_{2} \mathrm{O}\right)$ make an important contribution to Europe's net emissions of greenhouse gases. A recent continental study identified $\mathrm{N}_{2} \mathrm{O}$ as the single most important greenhouse gas emitted from landbased sources with emissions from Europe equivalent to $97 \mathrm{Tg} \mathrm{C} \mathrm{yr}^{-1}$ (Schulze et al., 2009). Agricultural soils used for grassland and arable production are a major source of $\mathrm{N}_{2} \mathrm{O}$, and strategies to reduce greenhouse gas emissions from the agricultural sector frequently highlight the importance of management interventions (Mosier et al., 1998; Rees et al., 2013). However, the contribution of management to mitigation can be difficult to assess against a background of fluxes that are highly variable in time and space, since emissions vary significantly in response to both climate and local environmental (particularly soil) conditions (Abdalla et al., 2010; Flechard et al., 2007; Skiba and Ball, 2002).

We now have a good understanding of the importance of individual variables in determining emissions, through their effect on the source processes of nitrification and denitrification (Dobbie and Smith, 2001; Smith et al., 1998; Wrage et al., 2001). Meta-analyses have shown that rates of fertiliser application, and soil properties, such as organic matter content, texture, drainage, $\mathrm{pH}$, fertiliser timing and rate, all influence emissions (Bouwman et al., 2002). Within a farming system these factors interact with local climatic conditions to determine overall rates of emission. Climate has been shown to be particularly important in influencing emissions even under constant management. A study of European grasslands showed that the proportion of $\mathrm{N}$ released as $\mathrm{N}_{2} \mathrm{O}$ from fertilisers (emission factor) could vary from 0.01 to $3.6 \%$, compared with the IPCC default value of $1 \%$ (Flechard et al., 2007). Applications of constant amounts of fertiliser $\mathrm{N}$ to a grassland site in the UK over several years resulted in variation emission factors in different years of between 0.3 and $7 \%$, largely as a consequence of varying climatic condi-

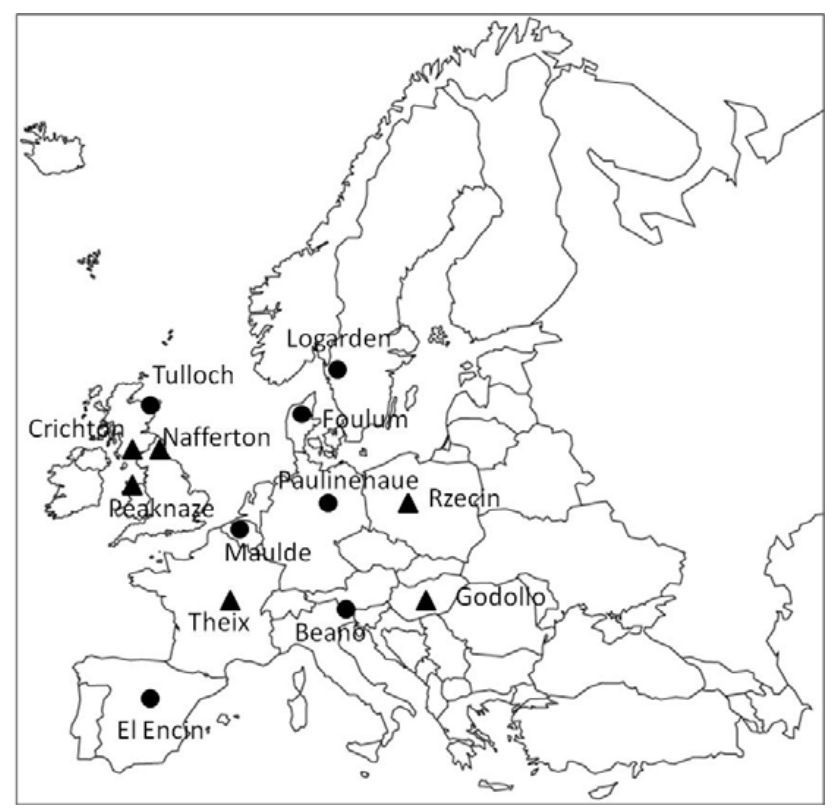

Fig. 1. Locations of the European experimental sites. Circles represent arable sites and triangles grassland sites.

tions in different years (Smith and Dobbie, 2002). Variability in emission factors used for cereals was smaller, but still showed a five-fold variation.

Against such variability, it could be argued that management interventions make a relatively small contribution to the mitigation of emissions. Furthermore, such interventions are constrained by the societal needs to maintain food production, and the most attractive mitigation options are therefore those that increase utilisation of added $\mathrm{N}$, and in so doing reducing losses.

In order to explore the relative importance of management, climate and site variability in influencing $\mathrm{N}_{2} \mathrm{O}$ emissions, we have used a network of 14 experimental sites (eight arable and six grassland) established as a part of the NitroEurope project, for the measurement and reporting of $\mathrm{N}_{2} \mathrm{O}$ emissions and related environmental drivers. At each site a range of management interventions were compared. Total annual emissions of $\mathrm{N}_{2} \mathrm{O}$ from different treatment sites and years showed wide variability. Single variables were often poor predictors of emissions, and so multivariate statistical techniques were used to explore the relationships between annual emissions and underlying driving variables. The aim was to quantify the magnitude of changes in $\mathrm{N}_{2} \mathrm{O}$ emission that could result from changes to agricultural management across a network of European sites.

\section{Materials and methods}

Manipulation experiments were established at sites across Europe in a coordinated research programme (NitroEurope) 
Table 1. An overview of the soil and climatic conditions across the experimental network.

\begin{tabular}{|c|c|c|c|c|c|c|c|}
\hline $\begin{array}{l}\text { Site name/ } \\
\text { Country }\end{array}$ & $\begin{array}{l}\text { Soil } \\
\text { texture }^{\mathrm{a}}\end{array}$ & $\begin{array}{c}\text { Soil } \\
\text { organic C } \\
\mathrm{g} \mathrm{kg}^{-1} \\
0-20 \mathrm{~cm}\end{array}$ & $\begin{array}{c}\text { Bulk } \\
\text { density } \\
\mathrm{g} \mathrm{cm}^{-3} \\
0-20 \mathrm{~cm}\end{array}$ & $\begin{array}{c}\text { Annual } \\
\text { average } \\
\text { temperature } \\
{ }^{\circ} \mathrm{C}\end{array}$ & $\begin{array}{c}\text { Annual } \\
\text { average } \\
\text { rainfall } \\
\mathrm{mm}\end{array}$ & Coordinates & Reference \\
\hline \multicolumn{8}{|l|}{ Arable } \\
\hline $\begin{array}{l}\text { Beano, } \\
\text { Italy }\end{array}$ & $\mathrm{L}$ & $17-20$ & $1.2-1.4$ & 13.2 & 1220 & $\begin{array}{l}56.30^{\prime} \mathrm{N} \\
9^{\circ} 34^{\prime} \mathrm{W}\end{array}$ & Alberti et al. (2010) \\
\hline $\begin{array}{l}\text { El Encin, } \\
\text { Spain }\end{array}$ & CL & $8-12$ & $1.3-1.4$ & 14.9 & 484 & $\begin{array}{l}40^{\circ} 32^{\prime} \mathrm{N} \\
3^{\circ} 37^{\prime} \mathrm{W}\end{array}$ & $\begin{array}{l}\text { Meijide et al. (2009); } \\
\text { Sanchez-Martin et al. (2010) }\end{array}$ \\
\hline $\begin{array}{l}\text { Foulum, } \\
\text { Denmark }\end{array}$ & SL & $22-23$ & 1.3 & 9.3 & 660 & $\begin{array}{c}56^{\circ} 30^{\prime} \mathrm{N} \\
9^{\circ} 35^{\prime} \mathrm{E}\end{array}$ & Chirinda et al. (2010) \\
\hline $\begin{array}{l}\text { Logården, } \\
\text { Sweden }\end{array}$ & $\mathrm{ZC}$ & $18-20$ & 1.4 & 7.9 & 695 & $\begin{array}{l}58^{\circ} 20^{\prime} \mathrm{N} \\
12^{\circ} 38^{\prime} \mathrm{E}\end{array}$ & Nylinder et al. (2011) \\
\hline $\begin{array}{l}\text { Maulde, } \\
\text { Belgium }\end{array}$ & $\mathrm{ZL}$ & $9-12$ & $1.3-1.5$ & 11.2 & 910 & $\begin{array}{c}50^{\circ} 37^{\prime} \mathrm{N}, \\
3^{\circ} 34^{\prime} \mathrm{E}\end{array}$ & Boeckx et al. (2011) \\
\hline $\begin{array}{l}\text { Paulinenaue, } \\
\text { Germany }\end{array}$ & Organic & $100-140$ & 0.5 & 9.7 & 694 & $\begin{array}{l}52^{\circ} 41^{\prime} \mathrm{N} \\
12^{\circ} 44^{\prime} \mathrm{E}\end{array}$ & Bell et al. (2012) \\
\hline $\begin{array}{l}\text { Tulloch, } \\
\text { UK }\end{array}$ & SL & $50-66$ & 1.2 & 8.9 & 940 & $\begin{array}{l}57^{\circ} 11^{\prime} \mathrm{N} \\
2^{\circ} 16^{\prime} \mathrm{W}\end{array}$ & $\begin{array}{l}\text { Ball et al. (2002); } \\
\text { Watson et al. (2011) }\end{array}$ \\
\hline $\begin{array}{l}\text { Harare, } \\
\text { Zimbabwe }\end{array}$ & $\mathrm{S} / \mathrm{C}$ & $5-8$ & 1.7 & 19.1 & 940 & $\begin{array}{l}17^{\circ} 55^{\prime} \mathrm{S} \\
30^{\circ} 55^{\prime} \mathrm{W}\end{array}$ & Mapanda et al. (2011) \\
\hline \multicolumn{8}{|l|}{ Grassland } \\
\hline $\begin{array}{l}\text { Crichton }{ }^{\mathrm{b}} \text {, } \\
\text { UK }\end{array}$ & SL & 29 & 1.1 & 10.1 & 1183 & $\begin{array}{l}55^{\circ} 02^{\prime} \mathrm{N} \\
3^{\circ} 35^{\prime} \mathrm{W}\end{array}$ & Gordon et al. (2011) \\
\hline $\begin{array}{l}\text { Gödöllö, } \\
\text { Hungary }\end{array}$ & SL & $17-41$ & 1.1 & 9.9 & 582 & $\begin{array}{l}47^{\circ} 60^{\prime} \mathrm{N} \\
19^{\circ} 37^{\prime} \mathrm{E}\end{array}$ & Horvath et al. (2010) \\
\hline $\begin{array}{l}\text { Nafferton, } \\
\text { UK }\end{array}$ & NA & NA & 1.1 & 9.5 & 664 & $\begin{array}{c}54.51^{\prime} \mathrm{N} \\
7.36^{\prime} \mathrm{E}\end{array}$ & Reay (unpublished data) \\
\hline $\begin{array}{l}\text { Peaknaze, } \\
\text { UK }\end{array}$ & NA & NA & 0.18 & 9.2 & 875 & $\begin{array}{l}53.47^{\prime} \mathrm{N} \\
13.91^{\prime} \mathrm{W}\end{array}$ & Levy et al. (2012) \\
\hline $\begin{array}{l}\text { Rzecin, } \\
\text { Poland }\end{array}$ & Organic & 420 & 0.06 & 8.5 & 536 & $\begin{array}{l}52^{\circ} 45^{\prime} \mathrm{N} \\
16^{\circ} 18^{\prime} \mathrm{E}\end{array}$ & Chojnicki et al. (2007); \\
\hline $\begin{array}{l}\text { Zarnekow }{ }^{\mathrm{c}} \text {, } \\
\text { Germany }\end{array}$ & Organic & 277 & 0.38 & 12.0 & 730 & $\begin{array}{l}53^{\circ} 52^{\prime} \mathrm{N} \\
12^{\circ} 53^{\prime} \mathrm{E}\end{array}$ & Juszczak et al. (2012) \\
\hline $\begin{array}{l}\text { Theix, } \\
\text { France }\end{array}$ & SL & NA & 1.1 & 7.8 & 704 & $\begin{array}{l}45^{\circ} 47^{\prime} \mathrm{N} \\
03^{\circ} 05^{\prime} \mathrm{E}\end{array}$ & Cantarel et al. $(2011,2012)$ \\
\hline
\end{tabular}

designed to cover a wide range of climatic conditions. At each site, a selection of management interventions were compared within replicated experimental designs in plot-based experiments. Each experiment was used to determine how changes in agricultural management or land use could affect $\mathrm{N}_{2} \mathrm{O}$ emissions. Arable experiments were conducted at Beano in Italy, El Encin in Spain, Foulum in Denmark, Logården in Sweden, Maulde in Belgium, Paulinenaue in Germany, and Tulloch in the UK (Fig. 1). Some comparisons of European emissions data were also made with linked experiments undertaken in Harare, Zimbabwe. Grassland experiments were conducted at Crichton, Nafferton and Peaknaze in the UK, Gödöllö in Hungary, Rzecin in Poland,
Zarnekow in Germany and Theix in France. At the arable sites the treatments included alternative tillage treatments, organic and conventional system management, changes in nutrient management (including the amount and form of $\mathrm{N}$ added), land use change and drainage treatments. On the grassland sites, treatments included variations in $\mathrm{N}$ inputs, wetting, and changes in temperature and atmospheric $\mathrm{CO}_{2}$ concentration (see Table 1 for a description of the experimental sites). At each site $\mathrm{N}_{2} \mathrm{O}$ fluxes were measured using closed static chambers over a period of two years or more, with a minimum of 20 measurements per year (and often including more intensive measurements in periods where fluxes were anticipated, for example following 
Table 2. A description of the experimental and analytical procedures used at each site.

\begin{tabular}{|c|c|c|c|}
\hline Site name & $\begin{array}{l}\text { Quantitative characteristics } \\
\text { (replicate chambers per } \\
\text { treatment; sampling } \\
\text { frequency per year; } \\
\text { samples per chamber; } \\
\text { chamber closure time in } \\
\text { minutes) }\end{array}$ & Methodology & Integration \\
\hline \multicolumn{4}{|l|}{ Arable } \\
\hline Beano & $3 ;>20 ; 3 ; 60$ & Gas chromatography & Linear interpolation \\
\hline El Encin & $3 ;>20 ; 3 ; 60$ & Gas chromatography & Linear interpolation \\
\hline Foulum & $4 ;>24 ; 3 ; 90-180$ & Gas chromatography & Linear interpolation \\
\hline Logården & $4 ;>20 ; 3 ; 60$ & Gas chromatography & $\begin{array}{l}\text { Linear interpolation } \\
\text { and modelling }\end{array}$ \\
\hline Maulde & $6 ;>20 ; 6 ; 60$ & Photoacoustic analyser & $\begin{array}{l}\text { Linear or non-linear regression } \\
\text { (Hutchinson and Mosier, 1981) }\end{array}$ \\
\hline Paulinenaue & $6 ;>20 ; 4 ; 60$ & Gas chromatography & Linear interpolation \\
\hline Tulloch & $3 ;>25 ; 2-6 ; 60$ & Gas chromatography & Linear interpolation \\
\hline Harare & $3 ;>20 ; 2-6 ; 60$ & Gas chromatography & Linear interpolation \\
\hline \multicolumn{4}{|l|}{ Grassland } \\
\hline Crichton & $3 ;>25 ; 2-6 ; 60$ & Gas chromatography & Linear interpolation \\
\hline Gödöllö & $3 ;>20 ; 4 ; 30$ & Gas chromatography & Linear interpolation \\
\hline Nafferton & $6 ;>20 ; 4 ; 60$ & Gas chromatography & Linear interpolation \\
\hline Peaknaze & $3 ;>20 ; 4 ; 60$ & Gas chromatography & Linear interpolation \\
\hline Rzecin/Zarnekow & $3 ;>25 ; 2-6 ; 60$ & Gas chromatography & Linear interpolation \\
\hline Theix & $3 ;>20 ; 5 ; 60$ & Photoacoustic analyser & Linear interpolation \\
\hline
\end{tabular}

fertiliser applications). Many of the experiments compared in this study had been established prior to the start of the measurement period reported in this paper, and hence there were minor variations in experimental approaches (noted below). However, as far as possible, the methodology used for determining fluxes was standardised across sites (Table 2 and NitroEurope, unpublished). A total of $590 \mathrm{yr}$ of data from individual plot combinations of treatment sites and years were compared in this analysis.

Many of the different chambers used in this study were compared in order to understand the importance of chamber design in determining its ability to quantify a flux (Pihlatie et al., 2013). Gas samples were collected in evacuated glass vials (or flushed through vials using a pump (Logården)) and analysed by gas chromatography at all sites except the Belgian and French sites, where photoacoustic infrared spectroscopy was used (Boeckx et al., 2011; Cantarel et al., 2011), and fluxes calculated according to standard methodologies (Dobbie and Smith, 2003). Further details of the methodology used to estimate emissions are provided in the individual site references (Table 1) and in Table 2.

Measurements of soil carbon, $\mathrm{N}, \mathrm{pH}$, texture, and bulk density were made once at each site (Table 1). Records of biological $\mathrm{N}$ fixation where legumes were present (using an empirical approach; Hogh-Jensen et al., 2004), N deposition (EMEP, 2012), and $\mathrm{N}$ removal by crops were also reported for each site. Annual $\mathrm{N}_{2} \mathrm{O}$ emissions were estimated cumulatively by linear interpolation between individual events. The data were collated and $\mathrm{N}_{2} \mathrm{O}$ data were log transformed $\left(\ln \mathrm{N}_{2} \mathrm{O}+1\right)$ prior to graphical presentation and analysis using multiple linear regression in GenStat (14th Edition) and Minitab (16th Edition). In the analysis, the random factor was specified to take into consideration site, year, block, replicate and treatments.

\section{Results}

Nitrous oxide fluxes varied widely between sites and as a result of manipulation treatments. Average site emissions (throughout the study period) varied between 0.04 and $21.21 \mathrm{~kg} \mathrm{~N}_{2} \mathrm{O}-\mathrm{N} \mathrm{ha}^{-1} \mathrm{yr}^{-1}$ (Fig. 2, Tables 3 and 4), with largest fluxes and variability associated with the grassland sites. Within the arable sites the fluxes varied between 0.6 and $5.3 \mathrm{~kg} \mathrm{~N}_{2} \mathrm{O}-\mathrm{Nha}^{-1} \mathrm{yr}^{-1}$, with the highest average fluxes observed from the Belgium tillage experiment at Maulde. The highest average grassland flux (21.2 $\mathrm{kg} \mathrm{N}_{2} \mathrm{O}-\mathrm{N} \mathrm{ha}^{-1} \mathrm{yr}^{-1}$ ) was observed from Crichton, an experiment located on an intensive dairy farm (receiving high inputs of inorganic and organic N) in the south-west of Scotland.

Within each site there was considerable variability in $\mathrm{N}_{2} \mathrm{O}$ emissions resulting from year-to-year changes in climatic 
(a) Arable

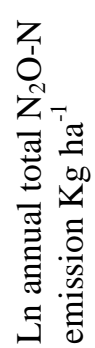

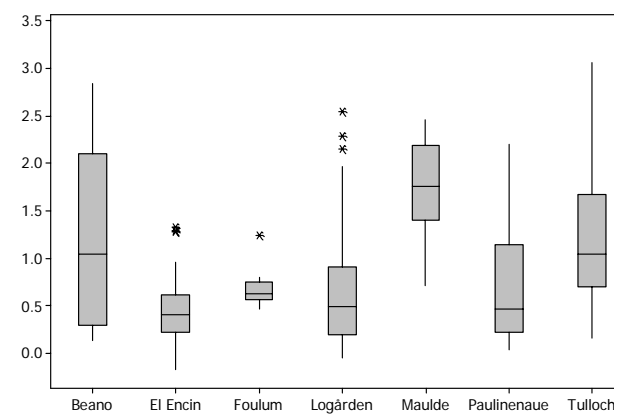

(b) All grassland sites

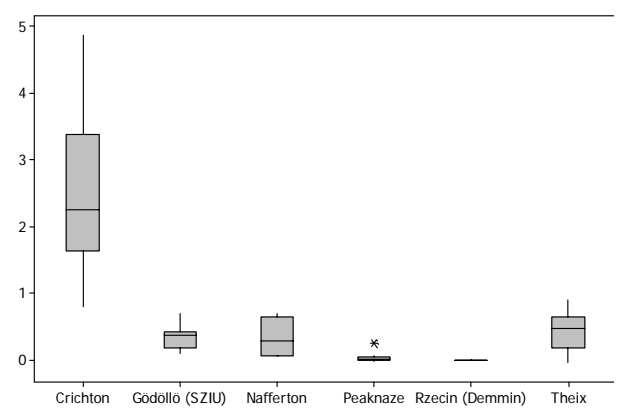

(c) The grassland site at Crichton. Treatments represent different fields. $\mathrm{F}=$ fertilised, NF = not fertilised.

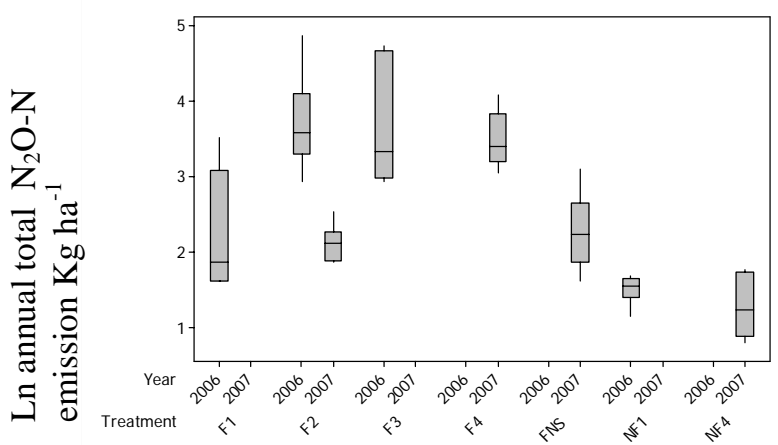

Fig. 2. Annual $\mathrm{N}_{2} \mathrm{O}$ emissions compared between sites. Each bar represents the average emission from different treatments in different years. Each bar indicates the mean (central bar), upper and lower quartiles (outside bar) and $95 \%$ range (lines). Outliers are represented by asterisks. See Table 3 for a description of the detailed treatment codes.

conditions and the manipulation treatments applied. An example of this variability is illustrated by considering fluxes from the Crichton grassland site. The annual average emission was $21.2 \mathrm{~kg} \mathrm{~N}_{2} \mathrm{O}-\mathrm{N} \mathrm{ha}^{-1} \mathrm{yr}^{-1}$; however, this varied between 2.9 and $51.3 \mathrm{~kg} \mathrm{~N}_{2} \mathrm{O}-\mathrm{N} \mathrm{ha}^{-1} \mathrm{yr}^{-1}$ in different treatments in 2007 (Fig. 2c, Table 3). There was also an annual variability (expressed as the difference between the mean emissions in each year) of $15.3 \mathrm{~kg} \mathrm{~N}_{2} \mathrm{O}-\mathrm{N} \mathrm{ha}^{-1} \mathrm{yr}^{-1}$.

A comparison of treatment effects and annual climatic effects across different sites demonstrated that treatments applied to arable sites resulted in a range of emissions between treatments that was greater than that observed between sites (Table 3). At the Tulloch organic farming experiment for example, the range in treatment emissions (averaged over years) was $0.5-13.2 \mathrm{~kg} \mathrm{~N}_{2} \mathrm{O}-\mathrm{N} \mathrm{ha}^{-1} \mathrm{yr}^{-1}$, while the range in the mean emission across all European arable sites was between 0.6 and $5.31 \mathrm{~kg} \mathrm{~N}_{2} \mathrm{O}-\mathrm{N} \mathrm{ha}^{-1} \mathrm{yr}^{-1}$ (Table 3a).

The variability in annual flux data showed reasonable consistency across sites with the annual average flux being of similar magnitude to the standard deviation (Table 3). Annual variability within sites was also important. The range of emissions between years (averaged over all treatments) at the El Encin site was $0.31-0.97 \mathrm{~kg} \mathrm{~N}_{2} \mathrm{O}-\mathrm{N} \mathrm{ha}^{-1} \mathrm{yr}^{-1}$ (Table 4), which was less than the range between sites: $0.6-5.3 \mathrm{~kg} \mathrm{~N}_{2} \mathrm{O}-\mathrm{N} \mathrm{ha}^{-1} \mathrm{yr}^{-1}$ (Table 3a). At grassland sites there was a range between treatments of $2.9-51.3 \mathrm{~kg} \mathrm{~N}_{2} \mathrm{O}-\mathrm{N} \mathrm{ha}^{-1} \mathrm{yr}^{-1}$ at the Crichton site, which was comparable with the range of $0.00-21.21 \mathrm{~kg} \mathrm{~N}_{2} \mathrm{O}-\mathrm{N} \mathrm{ha}^{-1} \mathrm{yr}^{-1}$ between sites (Table $3 \mathrm{~b}$ ).

An analysis of all annual data from across the different sites and years was used to identify the importance of a range of driving variables. Within the arable sites total $\mathrm{N}$ input (in the form of organic $\mathrm{N}$ and/or synthetic $\mathrm{N}$ fertiliser) had a significant effect on the emissions $(p<0.001$; Fig. 3, Table 4a), with $\ln \mathrm{N}_{2} \mathrm{O}+1=0.70( \pm 0.15)+0.0018$ $( \pm 0.00029) \times$ total $\mathrm{N}$ applied

The total water (rainfall + irrigation) applied to the crop also had a significant effect $(p=0.0001)$ on the total emissions from the site; however, in this case the constant was no longer significant.

$\ln \mathrm{N}_{2} \mathrm{O}+1=0.0020( \pm 0.00028) \times$ total $\mathrm{N}$ applied +0.0061

$$
( \pm 0.00013) \times \text { total water }
$$


Table 3 . Nitrous oxide emissions (annual total) in response to site and management conditions across the experimental network classified by site and treatment.

\begin{tabular}{|c|c|c|}
\hline (a) Arable sites & Treatment & $\begin{array}{c}\text { Annual emission } \mathrm{N}_{2} \mathrm{O} \mathrm{kg}^{-1} \mathrm{ha}^{-1} \mathrm{yr}^{-1} \\
\text { Standard deviation in brackets }\end{array}$ \\
\hline \multirow[t]{3}{*}{ Beano } & Cropland no till (CNT) & $6.17(5.75)$ \\
\hline & Cropland tilled (CT) & $5.49(4.34)$ \\
\hline & Grassland tilled (GT) & $1.03(1.01)$ \\
\hline Beano Average & & $4.23(4.65)$ \\
\hline \multirow[t]{7}{*}{ El Encin } & Control $(C)$ & $0.21(0.22)$ \\
\hline & Composted crop residue (CCR) & $0.41(0.15)$ \\
\hline & Digested pig slurry (DPS) & $0.71(0.43)$ \\
\hline & Mixed organic waste (MSW) & $0.32(0.23)$ \\
\hline & Organic manure $(\mathrm{OM})$ & $0.89(0.12)$ \\
\hline & Urea $(U)$ & $1.17(0.81)$ \\
\hline & Untreated slurry (UPS) & $0.36(0.18)$ \\
\hline El Encin Average & & $0.63(0.59)$ \\
\hline \multirow[t]{3}{*}{ Foulum } & Conventional without catch crops $(C-\mathrm{CC}+M)$ & $1.24(0.82)$ \\
\hline & Organic with catch crops $(O+\mathrm{CC}+M)$ & $0.98(0.17)$ \\
\hline & Organic without catch crops $(O-\mathrm{CC}+M)$ & $0.83(0.25)$ \\
\hline Foulum Average & & $1.02(0.49)$ \\
\hline \multirow[t]{2}{*}{ Logården } & Integrated (Int) & $1.29(1.86)$ \\
\hline & Organic (Org) & $1.08(1.49)$ \\
\hline Logården Average & & $1.15(1.62)$ \\
\hline \multirow[t]{3}{*}{ Maulde } & Conventional tillage (CT) & $4.96(2.28)$ \\
\hline & No tillage (NT) & $5.68(2.69)$ \\
\hline & Reduced tillage (RT) & $5.28(3.39)$ \\
\hline Maulde Average & & $5.31(2.76)$ \\
\hline \multirow[t]{3}{*}{ Paulinenaue } & Arable (AC) & $2.83(2.17)$ \\
\hline & Arable converted to grassland (AG) & $0.39(0.36)$ \\
\hline & Permanent grassland $(\mathrm{PeM})$ & $1.15(1.99)$ \\
\hline Paulinenaue Average & & $1.46(1.95)$ \\
\hline \multirow[t]{14}{*}{ Tulloch } & Barley $(B)$ & $9.27(1.52)$ \\
\hline & Barley undersown ( $\left.B_{\mathrm{us}}\right)$ & $13.21(10.21)$ \\
\hline & Ley oats (LO) & $5.99(3.98)$ \\
\hline & Oats $(O)$ & $0.50(0.46)$ \\
\hline & Oats undersown $\left(O_{\mathrm{us}}\right)$ & $2.23(0.71)$ \\
\hline & Potato (Pot) & $8.45(8.23)$ \\
\hline & Swede $(S)$ & $3.07(4.80)$ \\
\hline & Wheat undersown $\left(W_{\mathrm{us}}\right)$ & $4.87(0.69)$ \\
\hline & First year grass (Y1G) & $0.72(0.34)$ \\
\hline & Second year grass (Y2G) & $1.12(0.80)$ \\
\hline & Third year grass (Y3G) & $1.90(1.25)$ \\
\hline & Fourth year grass (Y4G) & $1.34(0.43)$ \\
\hline & Pulses (Pul) & $3.10(1.32)$ \\
\hline & Grass red-clover (YGr) & $3.75(2.61)$ \\
\hline Tulloch Average & & $3.46(4.10)$ \\
\hline \multirow[t]{6}{*}{ Harare } & Control $(0 \mathrm{~N})$ & $0.85(1.01)$ \\
\hline & $30 \mathrm{~kg}$ ammonium nitrate- $\mathrm{N}(30 \mathrm{~kg} \mathrm{~N})$ & $0.48(0.88)$ \\
\hline & $30 \mathrm{~kg} \mathrm{AN}+$ manure $(\mathrm{N}+$ manure $)$ & $0.48(0.61)$ \\
\hline & $60 \mathrm{~kg}$ ammonium nitrate- $\mathrm{N}(60 \mathrm{~kg} \mathrm{~N})$ & $0.67(0.92)$ \\
\hline & $30 \mathrm{~kg}$ manure- $\mathrm{N}(30 \mathrm{~kg}$ manure $\mathrm{N})$ & $0.25(0.27)$ \\
\hline & $60 \mathrm{~kg}$ ammonium nitrate- $\mathrm{N}$ (60 kg manure-N) & $0.85(0.97)$ \\
\hline Harare Average & & $0.60(0.81)$ \\
\hline Grand Average & & $1.80(2.72)$ \\
\hline
\end{tabular}


Table 3 . Continued.

\begin{tabular}{|c|c|c|}
\hline (b) Grassland sites & Treatment & $\begin{array}{l}\text { Average of total } \mathrm{N}_{2} \mathrm{O}-\mathrm{N} \mathrm{kg}^{-1} \mathrm{ha}^{-1} \mathrm{yr}^{-1} \\
\text { Standard deviation in brackets }\end{array}$ \\
\hline \multirow[t]{7}{*}{ Crichton } & Site 1 fertilised \& grazed $(\mathrm{F} 1)$ & $11.68(11.63)$ \\
\hline & Site 2 fertilised \& grazed (F2) & $28.21(34.89)$ \\
\hline & Site 3 fertilised \& grazed (F3) & $51.27(44.28)$ \\
\hline & Site 4 fertilised \& grazed (F4) & $33.90(13.86)$ \\
\hline & Site 5 fertilised \& grazed (FNS) & $9.89(6.10)$ \\
\hline & Site 6 slurry \& grazed (NF1) & $3.62(0.80)$ \\
\hline & Site 7 slurry \& grazed (NF4) & $2.88(1.59)$ \\
\hline Crichton Average & & $21.21(28.13)$ \\
\hline \multirow[t]{4}{*}{ Gödöllö } & Control $(C)$ & $0.38(0.19)$ \\
\hline & Elevated $\mathrm{CO}_{2}\left(\mathrm{CO}_{2}\right)$ & $0.23(0.17)$ \\
\hline & Fertilizer $(F)$ & $0.62(0.30)$ \\
\hline & Wetted $(W)$ & $0.40(0.12)$ \\
\hline Gödöllö Average & & $0.41(0.23)$ \\
\hline \multirow[t]{2}{*}{ Nafferton } & Control $(C)$ & $0.55(0.66)$ \\
\hline & Wetted $(W)$ & $0.36(0.40)$ \\
\hline Nafferton Average & & $0.45(0.46)$ \\
\hline \multirow[t]{3}{*}{ Peaknaze } & Control $(C)$ & $0.04(0.03)$ \\
\hline & Drought $(D)$ & $0.09(0.16)$ \\
\hline & Warming $(T)$ & $0.00(0.03)$ \\
\hline Peaknaze Average & & $0.04(0.09)$ \\
\hline Rzecin/ & Control $(C)$ & $0.526(0.001)$ \\
\hline \multirow[t]{2}{*}{ Zarnekow } & Dry/wet grassland (DW) & $0.004(0.001)$ \\
\hline & Re-flooded grassland (RF) & $0.004(0.001)$ \\
\hline Rzecin/ Zarnekow & & $0.04(0.013)$ \\
\hline Average & & \\
\hline \multirow[t]{4}{*}{ Theix } & Control $(C)$ & $0.52(0.43)$ \\
\hline & Increased temperature $(T)$ & $0.69(0.46)$ \\
\hline & Increased temperature \& drought (TD) & $0.64(0.47)$ \\
\hline & Inc. temperature, $\mathrm{CO}_{2} \&$ drought $\left(\mathrm{TDCO}_{2}\right)$ & $0.63(0.44)$ \\
\hline Theix Average & & $0.62(0.44)$ \\
\hline Grand Average & & $7.00(18.45)$ \\
\hline
\end{tabular}

In the case of the grassland sites, total $\mathrm{N}$ applied was also significant ( $p<0.0001$; Fig. 3, Table 4).

$\ln \mathrm{N}_{2} \mathrm{O}+1=0.32( \pm 0.15)+0.0062( \pm 0.00070) \times$ total $\mathrm{N}$ applied $(2)$

Similarly to the arable sites, the total annual rainfall $(p<0.0001)$ was also an important determinant of emissions from grassland sites.

$\ln \mathrm{N}_{2} \mathrm{O}+1=-0.42( \pm 0.21)+0.00059( \pm 0.00063) \times$ total $\mathrm{N}$ applied

$$
+0.00096( \pm 0.00023) \times \text { total water }
$$

The high $\mathrm{N}$ additions and $\mathrm{N}_{2} \mathrm{O}$ emissions from the Crichton grasslands were important in contributing to the strength of this regression. Another notable feature of this regression analysis was the wide range of emissions $\left(0-21 \mathrm{~kg} \mathrm{~N}_{2} \mathrm{O}-\mathrm{Nha}^{-1}\right)$ associated with sites receiving no added $\mathrm{N}$ (synthetic fertiliser or manure). It was noted that soil organic carbon (SOC) and bulk density were not significant factors for either arable or grassland sites.

The emissions data presented here can also be used to identify those systems with the highest emissions (and therefore greatest mitigation potential). When the data from all 438 combinations of site and treatment years from the arable experiments were compared, the ten highest emissions were observed at just three sites when expressed on an emission per unit area basis: these were Tulloch, Beano, and Maulde (Fig. 4). When expressed on an intensity basis, the ten highest emissions were also observed at three sites: Tulloch, Harare and Logården, with values ranging from 0.06 to $0.8 \mathrm{~kg} \mathrm{~N}_{2} \mathrm{O}-\mathrm{N} \mathrm{kg}$ total $\mathrm{N}$ added $^{-1}$ (Fig. 4). Emissions from the grassland sites were generally lower than those from the arable sites with the exception of Crichton where emissions were approximately two orders of magnitude higher than other grassland sites (Fig. 4). 
Table 4 . Nitrous oxide emissions in response to site and management conditions across the experimental network classified by site and year (average of total $\mathrm{N}_{2} \mathrm{O}-\mathrm{N} \mathrm{kg}^{-1} \mathrm{ha}^{-1} \mathrm{yr}^{-1} \pm$ standard deviation).

\begin{tabular}{|c|c|c|c|c|c|c|c|}
\hline & \multicolumn{7}{|c|}{ Year } \\
\hline & 2004 & 2005 & 2006 & 2007 & 2008 & 2009 & 2010 \\
\hline \multicolumn{8}{|l|}{ Arable sites } \\
\hline \multirow[t]{2}{*}{ Beano } & & & & 0.27 & 6.62 & 5.80 & \\
\hline & & & & \pm 0.10 & \pm 5.06 & \pm 4.23 & \\
\hline \multirow[t]{2}{*}{ El Encin } & & & $0.31 \pm 0.23$ & 0.71 & 0.79 & 0.97 & 0.50 \\
\hline & & & \pm 0.64 & \pm 0.47 & \pm 1.00 & \pm 0.55 & \\
\hline \multirow[t]{2}{*}{ Foulum } & & & & 1.15 & 0.89 & & \\
\hline & & & & \pm 0.67 & \pm 0.19 & & \\
\hline \multirow[t]{2}{*}{ Logården } & 1.72 & 1.76 & 1.03 & 0.19 & & & \\
\hline & \pm 1.26 & \pm 1.60 & \pm 2.08 & \pm 0.13 & & & \\
\hline \multirow[t]{2}{*}{ Maulde } & & & & 6.83 & 3.78 & & \\
\hline & & & & \pm 2.07 & \pm 2.54 & & \\
\hline \multirow[t]{2}{*}{ Paulinenaue } & & & & 2.73 & 1.04 & 0.59 & \\
\hline & & & & \pm 2.80 & \pm 1.13 & \pm 0.56 & \\
\hline \multirow[t]{2}{*}{ Tulloch } & & & 2.27 & 4.56 & & & \\
\hline & & & \pm 2.77 & \pm 4.83 & & & \\
\hline \multirow[t]{2}{*}{ Harare } & & & & 0.58 & 0.89 & 0.33 & \\
\hline & & & & \pm 0.84 & \pm 0.9 & \pm 0.6 & \\
\hline \multicolumn{8}{|l|}{ Grassland sites } \\
\hline \multirow[t]{2}{*}{ Crichton } & & & 28.86 & 13.55 & & & \\
\hline & & & \pm 35.96 & \pm 14.22 & & & \\
\hline \multirow[t]{2}{*}{ Gödöllö } & & & & 0.35 & 0.43 & & \\
\hline & & & & \pm 0.19 & \pm 0.25 & & \\
\hline \multirow[t]{2}{*}{ Nafferton } & & & 0.83 & 0.07 & & & \\
\hline & & & \pm 0.26 & \pm 0.00 & & & \\
\hline \multirow[t]{2}{*}{ Peaknaze } & & & & 0.04 & & & \\
\hline & & & & \pm 0.09 & & & \\
\hline \multirow[t]{2}{*}{ Rzecin } & & & & 0.00 & 0.00 & & \\
\hline & & & & \pm 0.16 & \pm 0.00 & & \\
\hline \multirow[t]{2}{*}{ Theix } & & & & 0.62 & 1.06 & 0.18 & \\
\hline & & & & \pm 0.23 & \pm 0.29 & \pm 0.26 & \\
\hline
\end{tabular}
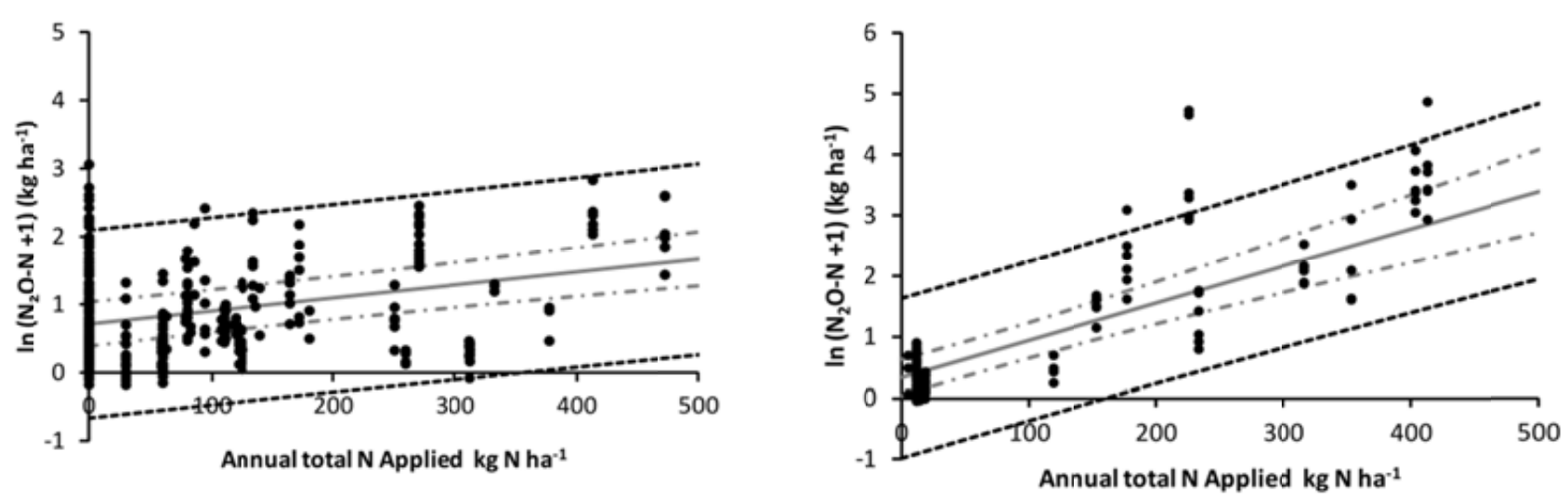

- Regression $-95 \% \mathrm{Cl} \quad \cdots$ UpperConf $\cdots 95 \%$ PI $\cdots 95 \% \mathrm{PI}$

Fig. 3. The relationship between $\mathrm{N}_{2} \mathrm{O}$ emissions and added $\mathrm{N}$ input (in the form of organic manures and synthetic $\mathrm{N}$ fertiliser) for (a) arable sites and (b) grassland sites. $\mathrm{Ln}\left(\mathrm{N}_{2} \mathrm{O}\right)\left(\mathrm{kg} \mathrm{N}_{2} \mathrm{O}-\mathrm{N} \mathrm{ha}^{-1}\right)$. The data set includes multiple data points from each site. 

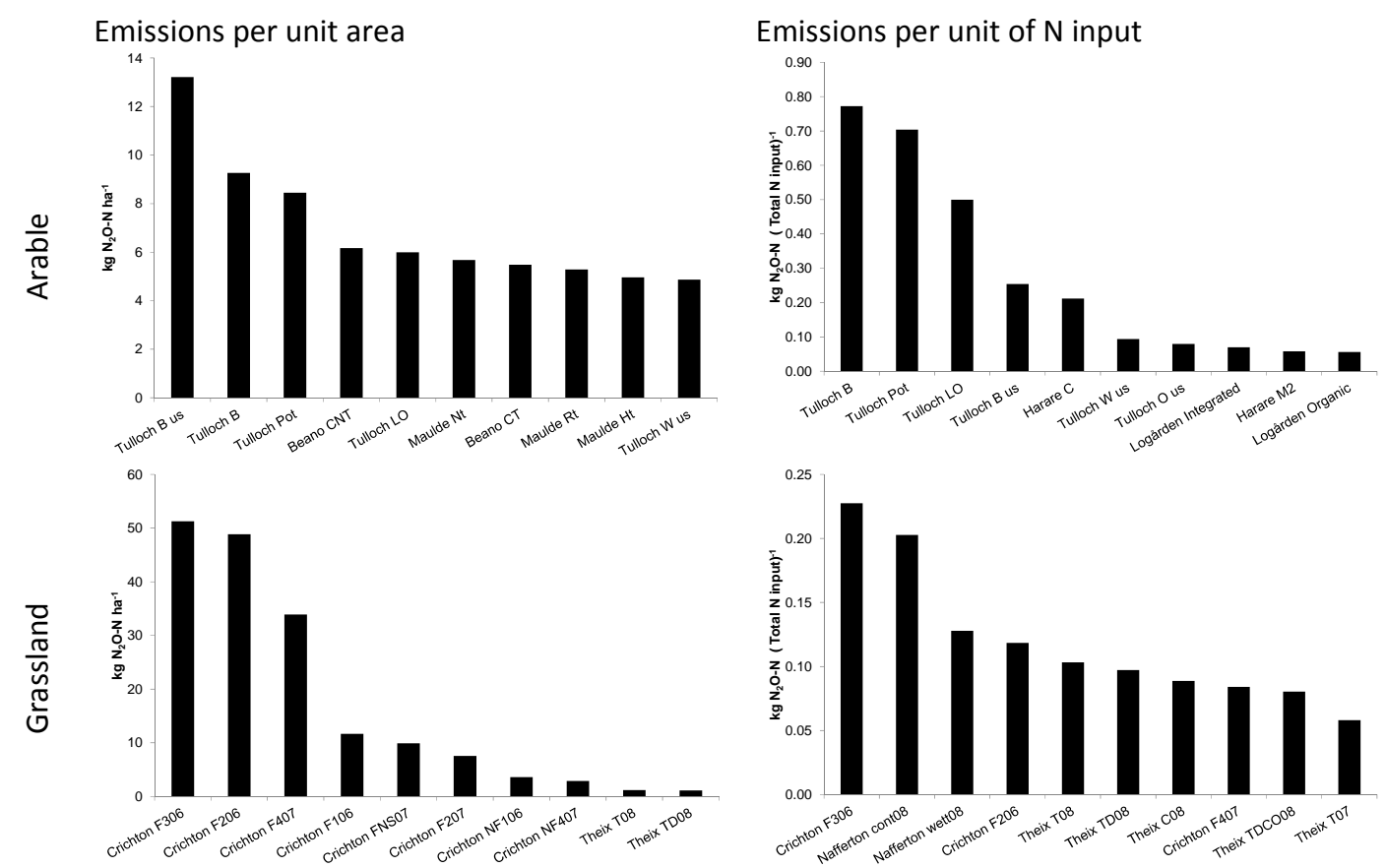

Fig. 4. Ranking of annual emissions data from individual arable plots. The top 10 sites are ranked on emissions per unit area $\left(\mathrm{kg} \mathrm{N}_{2} \mathrm{O}-\mathrm{N}\right.$ ha $\left.{ }^{-1}\right)$ and per unit of $\mathrm{N}_{2} \mathrm{O}$ per unit of $\mathrm{N}$ total input (synthetic fertiliser, manure and biological $\mathrm{N}$ fixation $\left(\mathrm{kg} \mathrm{N}_{2} \mathrm{O}-\mathrm{N} \mathrm{kg} \mathrm{N}\right.$ input $\left.{ }^{-1}\right)$. See Table 3 for a description of the treatment codes.

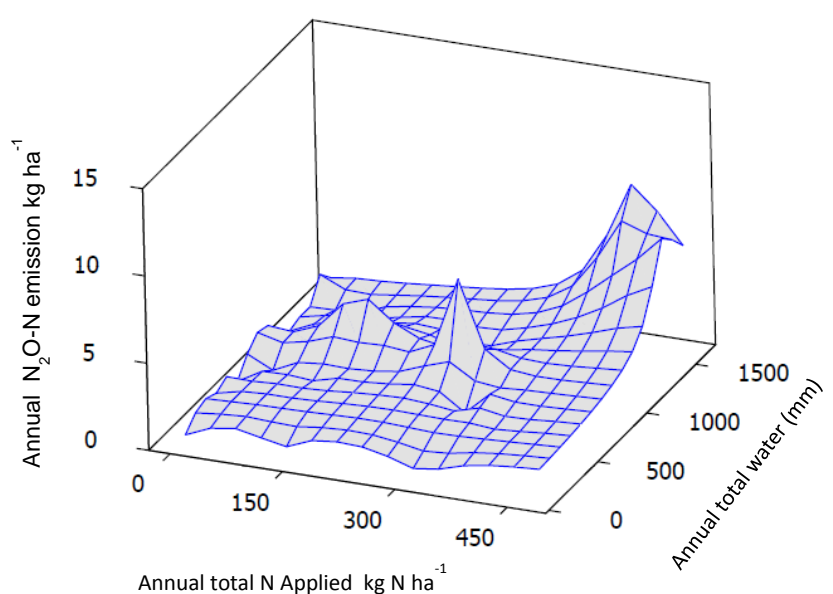

Fig. 5. The relationship between $\mathrm{N}_{2} \mathrm{O}$ emissions and annual total rainfall plus irrigation and total $\mathrm{N}$ input across the arable site network.

A three-dimensional plot of $\mathrm{N}_{2} \mathrm{O}$ emissions against annual total rainfall and irrigation and total annual $\mathrm{N}$ addition emphasises the combined effect of $\mathrm{N}$ addition and total water addition in determining emissions. Under dry conditions with $500 \mathrm{~mm}$ of rainfall or less, emissions remained below $3 \mathrm{~kg} \mathrm{~N}_{2} \mathrm{O}-\mathrm{Nha}^{-1}$ at rates of $\mathrm{N}$ application of up to $450 \mathrm{~kg} \mathrm{ha}^{-1}$. However, as the rainfall and irrigation increased to $1500 \mathrm{~mm}$, emissions rose to around $10 \mathrm{~kg} \mathrm{~N}_{2} \mathrm{O}-\mathrm{N} \mathrm{ha}^{-1}$ (Fig. 5).

\section{Discussion}

We know from previous studies that emissions of $\mathrm{N}_{2} \mathrm{O}$ from landscapes are controlled by site-specific factors such as soil conditions and climate as well as the way in which these systems are managed (e.g. fertiliser use and agronomy) (Dobbie et al., 1999; Smith and Conen, 2004). This study has allowed us to compare the relative magnitude of these effects across a large number of sites, and has demonstrated that the changes associated with management interventions are equal to or greater than those associated with differences between site and year. There was a large variability in fluxes observed as a consequence of manipulation treatments introduced within each site and between measurement years. Characterising the magnitude of potential mitigation is an essential prerequisite for the implementation of policies designed at reducing greenhouse gas emissions from the agricultural sector. It has been suggested that interventions which include better nutrient use efficiency, improved soil management and improved agronomy could achieve a reduction in emissions of 10-30 \% (Mosier et al., 1998; Smith et al., 1997). The results presented here are consistent with these estimates, and have highlighted the importance of reducing the $\mathrm{N}$ supply in order to contribute to mitigation.

The change in emissions associated with increasing $\mathrm{N}$ inputs observed in our experiments was not always consistent with those that would be estimated by default IPCC emissions factors, where $1 \%$ of added $\mathrm{N}$ would be predicted to be 
lost as $\mathrm{N}_{2} \mathrm{O}$ (IPCC, 2006). At the arable sites emissions were $37 \%$ greater than this value, and despite the large variability, this was significantly greater $(p<0.0001)$ than $1 \%$ of $\mathrm{N}$ inputs. The grassland sites did not show a significant difference from the default emission factor, but relatively few of these sites included $\mathrm{N}$ addition. The largest variation in emissions across treatments within an individual site was associated with changes in the inputs of $\mathrm{N}$ and cropping at the Scottish organic rotation at Tulloch (Table 3). This site reported a 26fold difference in emissions $\left(0.5-13.2 \mathrm{~kg} \mathrm{~N}_{2} \mathrm{O}-\mathrm{N} \mathrm{ha}^{-1} \mathrm{yr}^{-1}\right)$, across the different treatments (which included different years of the rotation). The effects of reduced tillage treatments resulted in a much smaller proportional change (increased $\mathrm{N}_{2} \mathrm{O}$ emissions) in Italy and Belgium (Alberti et al., 2010; Boeckx et al., 2011). However, it should be considered that reducing tillage intensity may also result in increased $\mathrm{C}$ storage, and so the effects on net greenhouse gas emissions may be less than those indicated by $\mathrm{N}_{2} \mathrm{O}$ emissions alone. There is also emerging evidence to suggest that, in the longer term, $\mathrm{N}_{2} \mathrm{O}$ emissions from reduced till systems may be lower than those from conventional tillage (Six et al., 2004).

There was a significant effect of $\mathrm{N}$ addition across all sites on $\mathrm{N}_{2} \mathrm{O}$ emissions, as illustrated by the regression analysis, which is consistent with previous meta-analyses of $\mathrm{N}_{2} \mathrm{O}$ emissions (Bouwman et al., 2002). However, it was not possible to explain more than $23 \%$ of the variability in emissions by $\mathrm{N}$ input from synthetic fertilisers and manures alone. The large range of emissions associated with sites receiving no $\mathrm{N}$ as fertiliser or manure is of particular importance. Many of these sites would receive $\mathrm{N}$ by biological fixation from leguminous crops sometimes over a period of several years prior to flux measurements. Biological $\mathrm{N}$ fixation is assumed by IPCC not to be directly associated with increased emissions of $\mathrm{N}_{2} \mathrm{O}$ (IPCC, 2006). Such systems may, however, generate increased emissions as a consequence of decomposition of $\mathrm{N}$-rich legume residues. The magnitude of such emissions remains highly uncertain and is likely to be highly site-specific (Baggs et al., 2000; Rochette and Janzen, 2005).

Another factor potentially contributing to emissions from unfertilised sites and not accounted for in this study would be the mineralisation of soil organic matter. Following land use change or within rotational systems, there may be a release of mineral $\mathrm{N}$ from the organic $\mathrm{N}$ pool due to tillage, providing a substrate for nitrification- and denitrification-driven $\mathrm{N}_{2} \mathrm{O}$ release. In organic farming systems this build-up of organic $\mathrm{N}$ within the grassland phase of a rotation is used to provide nutrients (particularly $\mathrm{N}$ ) for subsequent arable crops (Stockdale et al., 2001; Watson et al., 2011). This can lead to some high emissions in individual years from organic farming systems, particularly where the system exists in mild and wet climates such as that at Scottish organic site at Tulloch (despite no apparent input of $\mathrm{N}$ in that year). However, high emissions from individual years within an organic phase of an organic rotation are often offset by lower emissions during the grassland phase, giving relatively low emissions
Table 5a. The parameter estimates, standard errors and the probabilities for the coefficients included in the multiple regressions for the arable sites.

\begin{tabular}{lrrrr}
\hline Parameter & Estimate & s.e. & $t(431)$ & $t$ pr. \\
\hline Constant & -1.875 & 0.449 & -4.18 & $<0.001$ \\
Total N applied & 0.00214 & 0.000292 & 7.32 & $<0.001$ \\
Deposition & 0.0223 & 0.00318 & 7.02 & $<0.001$ \\
Average daily & -0.059 & 0.00779 & -7.57 & $<0.001$ \\
temperature & & & & \\
Total water & 0.00032 & 0.000104 & 3.03 & 0.003 \\
Bulk density & 1.65 & 0.276 & 5.95 & $<0.001$ \\
SOC & 0.151 & 0.0317 & 4.77 & $<.001$ \\
\hline
\end{tabular}

Table 5b. The parameter estimates, standard errors and the probabilities for the coefficients included in the multiple regressions for the grassland sites.

\begin{tabular}{lrrrr}
\hline Parameter & Estimate & s.e. & $t(148)$ & $t$ pr. \\
\hline Constant & -1.004 & 0.223 & -4.50 & $<0.001$ \\
Total N applied & 0.00572 & 0.000446 & 12.84 & $<0.001$ \\
Total rainfall & 0.00106 & 0.000205 & 5.17 & $<0.001$ \\
Bulk density & 0.618 & 0.150 & 4.12 & $<0.001$ \\
\hline
\end{tabular}

from the system overall (Ball et al., 2002). In this study the average of emissions over the three cropped organic sites was $1.58 \mathrm{~kg} \mathrm{~N}_{2} \mathrm{O}-\mathrm{N} \mathrm{ha}^{-1}$, compared with an overall mean of $2.37 \mathrm{~kg} \mathrm{~N}_{2} \mathrm{O}-\mathrm{N} \mathrm{ha}^{-1}$ from the arable sites.

There is a trade-off between reducing $\mathrm{N}_{2} \mathrm{O}$ emissions by reduced $\mathrm{N}$ input and food production, since restricting $\mathrm{N}$ input can often lead to proportional decreases in crop yields and an effective displacement of emissions. This is because reductions in emissions that are achieved by lowering production can lead to an import of food, which itself would be associated with emissions (Godfray et al., 2011).

For this reason the emissions intensity provides a useful index of the effectiveness of mitigation. Some of the highest emission intensities were associated with individual phases of organic rotations at Tulloch $\left(4.0 \mathrm{~g} \mathrm{~N}_{2} \mathrm{O}-\mathrm{N} \mathrm{kg} \mathrm{N}\right.$ uptake $\left.{ }^{-1}\right)$ and Logården ( $2.1 \mathrm{~g} \mathrm{~N}_{2} \mathrm{O}-\mathrm{N} \mathrm{kg} \mathrm{N}$ uptake ${ }^{-1}$ ). This highlights the need to increase the utilisation efficiency of $\mathrm{N}$ between different crop types within some production systems in order to lower emission intensities.

The implementation of mitigation measures to reduce $\mathrm{N}_{2} \mathrm{O}$ emissions from agriculture is likely to depend on regionally specific changes in management practice that take account of local soil and climatic conditions. We have shown that those locations associated with high $\mathrm{N}$ inputs and high annual rainfall and irrigation (above $1000 \mathrm{~mm}$ ) are most prone to large emissions. El Encin is an example of such a site, and studies there have identified inorganic fertiliser $\mathrm{N}$ as being a particularly important contributor to emissions. Studies at the Spanish site were able to demonstrate that replacement 
of fertiliser by organic $\mathrm{N}$ substrates or the combination of organic and synthetic fertiliser was able to reduce emissions of $\mathrm{N}_{2} \mathrm{O}$ significantly (Meijide et al., 2009; Sanchez-Martin et al., 2010).

A number of sites reported a net annual uptake of $\mathrm{N}_{2} \mathrm{O}$ within individual plots of a treatment. This included 12 plots at El Encin, seven from Zimbabwe, two at Logården and one at Maulde. Dry or well-drained soil conditions together with low $\mathrm{N}$ availability appear to favour net uptake. The mechanism responsible is uncertain, but it is likely to involve the use of $\mathrm{N}_{2} \mathrm{O}$ as a terminal electron acceptor in circumstances where soil aggregation allows uptake of $\mathrm{N}_{2} \mathrm{O}$ from the air into oxygen-depleted sites where $\mathrm{N}_{2} \mathrm{O}$ can be used instead of $\mathrm{O}_{2}$ (Neftel et al., 2007).

The grassland sites included in this study were very diverse but included only one highly intensive production system on a dairy farm in Scotland (Crichton). Here, emissions were higher than any measured from elsewhere at the arable and grassland sites. This was a reflection of the high $\mathrm{N}$ input (specifically in 2007 when total inputs in one treatment exceeded $600 \mathrm{~kg} \mathrm{Nha}^{-1} \mathrm{yr}^{-1}$ in some treatments) and mild and wet conditions that occur throughout the year, which are conducive to high $\mathrm{N}_{2} \mathrm{O}$ emissions (Flechard et al., 2007). The remaining grassland sites received much lower $\mathrm{N}$ inputs and were generally associated with low $\mathrm{N}_{2} \mathrm{O}$ emissions, highlighting the importance of $\mathrm{N}$ input in driving $\mathrm{N}_{2} \mathrm{O}$ emissions.

\section{Conclusion}

This study has allowed a wide-ranging comparison of the relative importance of agricultural management and sitespecific determinant of $\mathrm{N}_{2} \mathrm{O}$ emissions. The magnitude of emissions varies widely, and $\mathrm{N}$ input to systems was shown to be the principal driver across sites and treatments. Grasslands with high $\mathrm{N}$ input showed the largest annual emissions, but arable sites receiving high $\mathrm{N}$ and water inputs were also prone to large emissions, thus illustrating the importance of restricting $\mathrm{N}$ supply in controlling $\mathrm{N}_{2} \mathrm{O}$ emissions. There was a significantly greater emission of $\mathrm{N}_{2} \mathrm{O}$ from $\mathrm{N}$ added to arable sites than would be predicted from IPCC default emission factors. This study has also demonstrated that while sites (and climate) are important determinants of the magnitude of $\mathrm{N}_{2} \mathrm{O}$ emissions, agricultural management practices are of equal or greater importance.

Acknowledgements. The authors wish to acknowledge funding from the European Union's Framework 6 Integrated Project NitroEurope (Contract No. 017841) and matched national research funding for financial support.

Edited by: C. Beier

\section{References}

Abdalla, M., Jones, M., and Williams, M.: Simulation of $\mathrm{N}_{2} \mathrm{O}$ fluxes from Irish arable soils: effect of climate change and management,
Biol. Fert. Soils, 46, 247-260, 2010.

Alberti, G., le Vedove, G., Zuliani, M., Peressotti, A., Castaldi, S., and Zerbi, G.: Changes in $\mathrm{CO}_{2}$ emissions after crop conversion from continuous maize to alfalfa, Agr. Ecosyst. Environ., 136, 139-147, 2010.

Baggs, E. M., Watson, C. A., and Rees, R. M.: The fate of nitrogen from incorporated cover crop and green manure residues, Nutr. Cycl. Agroecosys., 56, 153-163, 2000.

Ball, B. C., McTaggart, I. P., and Watson, C. A.: Influence of organic ley-arable management and afforestation in sandy loam to clay loam soils on fluxes of $\mathrm{N}_{2} \mathrm{O}$ and $\mathrm{CH}_{4}$ in Scotland, Agr. Ecosyst. Environ., 90, 305-317, 2002.

Bell, M., Jones, E., Smith, J., Smith, P., Yeluripati, J., Augustin, J., Juszczak, R., Olejnik, J., and Sommer, M.: Simulation of soil nitrogen, nitrous oxide emissions and mitigation scenarios at 3 European cropland sites using the ECOSSE model, Nutr. Cycl. Agroecosys., 92, 161-181, 2012.

Boeckx, P., Van Nieuland, K., and van Cleemput, O.: Short-term effect of tillage intensity on $\mathrm{N}_{2} \mathrm{O}$ and $\mathrm{CO}_{2}$ emissions, Agron. Sustain. Dev., 31, 453-461, 2011.

Bouwman, A. F., Boumans, L. J. M., and Batjes, N. H.: Emissions of $\mathrm{N}_{2} \mathrm{O}$ and $\mathrm{NO}$ from fertilized fields: Summary of available measurement data, Global Biogeochem. Cy., 16, 1058, doi:10.1029/92GB02793, 2002.

Cantarel, A. A., Bloor, J. M., Deltroy, N., and Soussana, J. F.: Effects of Climate Change Drivers on Nitrous Oxide Fluxes in an Upland Temperate Grassland, Ecosystems, 14, 223-233, 2011.

Cantarel, A. A. M., Bloor, J. M. G., Pommier, T., Guillaumaud, N., Moirot, C., Soussana, J. F., and Poly, F.: Four-years of experimental climate change modifies the microbial drivers of $\mathrm{N}_{2} \mathrm{O}$ fluxes in an upland grassland ecosystem, Glob. Change Biol., 18, 2520-2531, 2012.

Chirinda, N., Carter, M. S., Albert, K. R., Ambus, P., Olesen, J. E., Porter, J. R. and Petersen, S. O.: Emissions of nitrous oxide from arable organic and conventional cropping sy-stems on two soil types, Agr. Ecosyst. Environ., 136, 199-208, 2010.

Chojnicki, B. H., Urbaniak, M., Jozefczyk, D., and Augustin, J.: Measurement of gas and heat fluxes in a Rzecin wetland, in: Wetlands: Monitoring, Modeling and Management, edited by: Okruszko, T., Taylor and Francis Group, London, 2007.

Dobbie, K. E. and Smith, K. A.: The effects of temperature, waterfilled pore space and land use on $\mathrm{N}_{2} \mathrm{O}$ emissions from an imperfectly drained gleysol, Eur. J. Soil. Sci., 52, 667-673, 2001.

Dobbie, K. E. and Smith, K. A.: Nitrous oxide emission factors for agricultural soils in Great Britain: the impact of soil water-filled pore space and other controlling variables, Glob. Change Biol., 9, 204-218, 2003.

Dobbie, K. E., McTaggart, I. P., and Smith, K. A.: Nitrous oxide emissions from intensive agricultural systems: Variations between crops and seasons, key driving variables, and mean emission factors, J. Geophys. Res.-Atmos., 104, 26891-26899, 1999.

EMEP: European Monitoring and Evaluation Programme (EMEP): http://www.emep.int, 2012.

Flechard, C. R., Ambus, P., Skiba, U. M., Rees, R. M., Hensen, A., van Amstel, A., Pol-van Dasselaar, A. V., Soussana, J. F., Jones, M., Clifton-Brown, J., Raschi, A., Horvath, L., Neftel, A., Jocher, M., Ammann, C., Leifeld, J., Fuhrer, J., Calanca, P., Thalman, E., Pilegaard, K., Di Marco, C., Campbell, C., Nemitz, E., Hargreaves, K. J., Levy, P. E., Ball, B. C., Jones, S. K., van de Bulk, W. 
C. M., Groot, T., Blom, M., Domingues, R., Kasper, G., Allard, V., Ceschia, E., Cellier, P., Laville, P., Henault, C., Bizouard, F., Abdalla, M., Williams, M., Baronti, S., Berretti, F., and Grosz, B.: Effects of climate and management intensity on nitrous oxide emissions in grassland systems across Europe, Agr. Ecosyst. Environ., 121, 135-152, 2007.

Godfray, H. C. J., Crute, I. R., Haddad, L., Lawrence, D., Muir, J. F., Pretty, J., Robinson, S., and Toulmin, C.: The Future of food and farming; Challenges and choices for global sustainability, London, UK, The Government office for Science, Foresight Report, 2011.

Gordon, H., Topp C. F. E., Nevison, I. M., Ball B. C., and Rees, R. M. Grassland Management and Climatic Effects on Nitrous Oxide Fluxes.: Tenth Conference Proceedings, September 2011, Belfast, UK, British Grassland Society, 2011.

Horvath, L., Grosz, B., Machon, A., Tuba, Z., Nagy, Z., Czobel, S., Balogh, J., Peli, E., Foti, S. Z., Weidinger, T., Pinter, K., and Fuhrer, E.: Estimation of nitrous oxide emission from Hungarian semi-arid sandy and loess grasslands; effect of soil parameters, grazing, irrigation and use of fertilizer, Agr. Ecosyst. Environ., 139, 255-263, 2010.

Hogh-Jensen, H., Loges, R., Jorgensen, F. V., Vinther, F. P., and Jensen, E. S.: An empirical model for quantification of symbiotic nitrogen fixation in grass-clover mixtures, Agr. Syst., 82, 181194, 2004.

IPCC: 2006 IPCC Guidelines for National Greenhouse Gas Inventories, Prepared by the National Greenhouse Gas Inventories Programme, edited by: Eggleston, H. S., Buendia, L., Miwa, K., Ngara, T., and Tanabe, K., IGES, Kanagawa, Japan, 2006.

Juszczak, R., Acosta, M., and Olejnik, J.: Comparison of daytime and nighttime ecosystem respiration measured by the closed chamber technique on wetland site, Rzecin case study, Polish Journal of Environmental Studies, 21, 643-658, 2012

Levy, P. E., Burden, A., Cooper, M. D. A., Dinsmore, K. J., Drewer, J., Evans, C.,Fowler, D., Gaiawyn, J., Gray, A., Jones, S. K., Jones, T., McNamara, N. P., Mills, R., Ostle, N., Sheppard, L. J., Skiba, U., Sowerby, A., Ward, S. E., and Zielinski, P.: Methane emissions from soils: synthesis and analysis of a large UK data set, 18, 1657-1669, doi:10.1111/j.1365-2486.2011.02616.x, 2012.

Mapanda,F., Wuta, M., Nyamangara, J., and Rees, R. M.: Effects of organic and mineral fertilizer nitrogen on greenhouse gas emissions and plant-captured carbon under maize cropping in Zimbabwe, Plant Soil, 343, 67-81, 2011.

Meijide, A., Garcia-Torres, L., Arce, A., and Vallejo, A.: Nitrogen oxide emissions affected by organic fertilization in a nonirrigated Mediterranean barley field, Agr. Ecosyst. Environ., 132, 106-115, 2009.

Mosier, A. R., Duxbury, J. M., Freney, J. R., Heinemeyer, O., and Minami, K.: Assessing and mitigating $\mathrm{N}_{2} \mathrm{O}$ emissions from agricultural soils, Climatic Change, 40, 7-38, 1998.

Neftel, A., Flechard, C., Ammann, C., Conen, F., Emmenegger, L., and Zeyer, K.: Experimental assessment of $\mathrm{N}_{2} \mathrm{O}$ background fluxes in grassland systems, Tellus B, 59, 470-482, 2007.

Nylinder, J., Stenberg, M., Jansson, P. E., Klemedtsson, A. K., Weslien, P., and Klemedtsson, L.: Modelling uncertainty for nitrate leaching and nitrous oxide emissions based on a Swedish field experiment with organic crop rotation, Agr. Ecosyst. Environ., 141, 167-183, 2011.
Pihlatie, M., Christiansen, J. R., Aaltonen, H., Korhonen, J., Nordbo, A., Rasilo, T., Benanti, G., Giebels, M., Helmy, M., Hirvensalo, J., Jones, S., Juszczak, R., Klefoth, R., Lobo do Vale, R., Rosa, A. P., Schreiber, P., Serça, D., Vicca, S., Wolf, B., and Pumpanen, J.: Comparison of static chambers to measure $\mathrm{CH}_{4}$ emissions from soils, Agr. Forest Meteorol., 171-172, 124-136, 2013. .

Rees R. M., Baddeley, J. A., Bhogal, A., Ball, B. C., Chadwick, D. R., Macleod, M., Lilly, A., Pappa, R., Thorman, R., Watson, C. A., and Williams, J. R.: Nitrous oxide mitigation in UK agriculture, Soil Sci. Plant Nutr., 59, 3-15. 2013.

Rochette, P. and Janzen, H.: Towards a revised coefficient for estimating $\mathrm{N}_{2} \mathrm{O}$ emissions from legumes, Nutr. Cycl. Agroecosys., 73, 171-179, 2005.

Sanchez-Martin, L., Meijide, A., Garcia-Torres, L., and Vallejo, A.: Combination of drip irrigation and organic fertilizer for mitigating emissions of nitrogen oxides in semiarid climate, Agr. Ecosyst. Environ., 137, 99-107, 2010.

Schulze, E. D., Luyssaert, S., Ciais, P., Freibauer, A., and Janssens, E. A.: Importance of methane and nitrous oxide for Europe's terrestrial greenhouse-gas balance, Nat. Geosci., 2, 842-850, 2009.

Six, J., Ogle, S. M., Breidt, F. J.,Conant, R. T., Mosier, A. R., and Paustian, K.: The potential to mitigate global warming with notillage management is only realized when practised in the long term, Glob Change Biol., 10, 155-160, 2004.

Skiba, U. and Ball, B.: The effect of soil texture and soil drainage on emissions of nitric oxide and nitrous oxide, Soil Use Manage., 18, 56-60, 2002.

Smith, K. A. and Conen, F.: Impacts of land management on fluxes of trace greenhouse gases, Soil Use Manage., 20, 255-263, 2004

Smith, K. A. and Dobbie, K. E.: Another look at $\mathrm{N}_{2} \mathrm{O}$ emission factors for agricultural soils, and implications for inventory calculations, in: Non- $\mathrm{CO}_{2}$ Greenhouse Gases: Scientific Understanding, Control Options and Policy Aspects, edited by: van Ham, J., Baede, A. P. M., Guicherit, R., and Williams-Jacobse, J. G. F. M., Millpress, Rotterdam, 245-250, 2002.

Smith, K. A., McTaggart, I. P., and Tsuruta, H.: Emissions of $\mathrm{N}_{2} \mathrm{O}$ and $\mathrm{NO}$ associated with nitrogen fertilization in intensive agriculture, and the potential for mitigation, Soil Use Manage., 13, 296-304, 1997.

Smith, K. A., Thomson, P. E., Clayton, H., McTaggart, I. P., and Conen, F.: Effects of temperature, water content and nitrogen fertilisation on emissions of nitrous oxide by soils, Atmos. Environ., 32, 3301-3309, 1998.

Stockdale, E. A., Lampkin, N. H., Hovi, M., Keatinge, R., Lennartsson, E. K. M., Macdonald, D. W., Padel, S., Tattersall, S. H., Wolfe, M. S., and Watson, C. A.: Agronomic and environmental implications of organic farming systems, Adv. Agron., 70, 261327, 2001.

Watson, C. A., Baddeley, J. A., Edwards, A. C., Rees, R. M., Walker, R. L., and Topp, C. F. E.: Influence of ley duration on the yield and quality of the subsequent cereal crop (spring oats) in an organically managed long-term crop rotation experiment, Org. Agr., 1, 147-159, 2011.

Wrage, N., Velthof, G. L., van Beusichem, M. L., and Oenema, O.: Role of nitrifier denitrification in the production of nitrous oxide, Soil Biol. Biochem., 33, 1723-1732, 2001. 